\title{
Phyllodes tumour arising in the ectopic axillary breast tissue, mimicking axillary lymphadenopathy
}

\author{
Akihiro Fujimoto @ (), Kazuo Matsuura, Takahiro Hasebe, Toshiaki Saeki
}

Breast Oncology Service, Saitama Medical University International Medical Center, Hidaka, Saitama, Japan

\section{Correspondence to} Akihiro Fujimoto; afujimot@saitama-med.ac.jp

Accepted 7 May 2021
D Check for updates

(c) BMJ Publishing Group Limited 2021. No commercial re-use. See rights and permissions. Published by BMJ.

\begin{tabular}{|l|}
\hline To cite: Fujimoto A, \\
Matsuura K, Hasebe T, \\
et al. BMJ Case Rep \\
2021;14:e243341. \\
doi:10.1136/bcr-2021- \\
243341 \\
\hline
\end{tabular}

\section{DESCRIPTION}

A 46-year-old woman came to our hospital with a right axillary mass. She had no significant medical or family history of cancer. There were no abnormal findings in the bilateral breasts on palpation, mammography or ultrasound (US), but a hard, elastic mass of approximately $20 \mathrm{~mm}$ was palpated in the right axilla. US showed an oval, wellcircumscribed hypoechoic mass with a major axis of $25 \mathrm{~mm}$ in the right axilla, suggesting right axillary lymphadenopathy (figure 1A). A contrast-enhanced CT whole-body scan revealed a well-defined mass on the right axilla near the medial upper arm. However, there were no other abnormal findings in the lymph nodes in the right axillary region or any other sites (figure 1B). There was also no evidence of primary malignancy in the breasts or other organs. She underwent US-guided core needle biopsy and was diagnosed with a fibroepithelial tumour, which suggested a fibroadenoma or phyllodes tumour. A tumourectomy was performed based on patient preference. The postoperative pathological findings confirmed that the tumour was a benign phyllodes tumour (figure 2A-C). Epithelial and stromal growth showing leaf-like architecture was observed. Ectopic breast tissue (EBT) was present around the tumour (figure 2B), suggesting that the tumour arose in the axillary EBT. EBT can be found at any point along the milk lines, which extend from the axilla

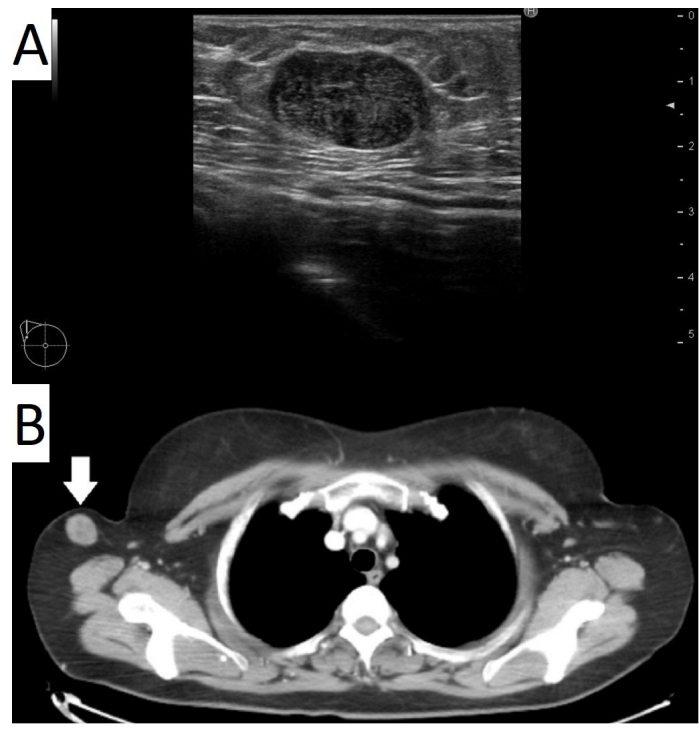

Figure 1 A well-circumscribed, oval hypoechoic mass with a major axis of $25 \mathrm{~mm}$ was observed in the right axilla on ultrasound (A). Contrast-enhanced CT scan revealed a mass with a well-defined contrast effect on the right axilla near the upper arm (white arrow) (B).

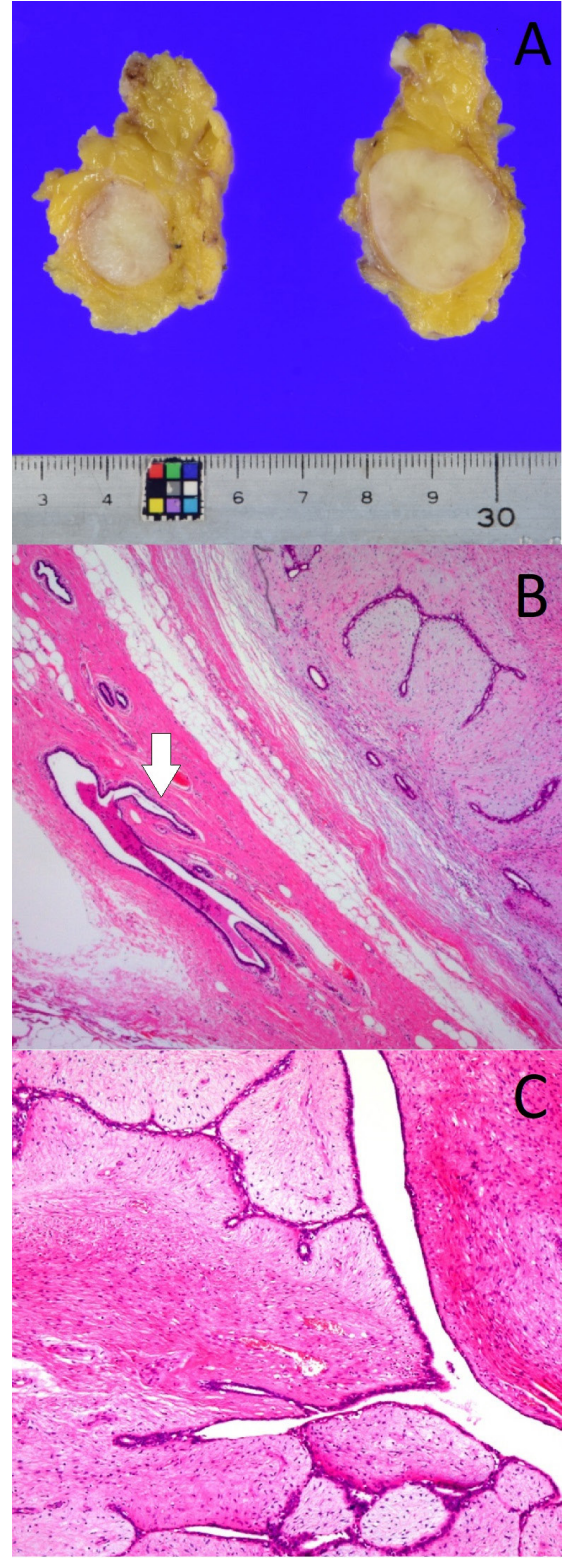

Figure 2 Macroscopic findings of the resected specimen (A). Histological findings from the surgical specimen ( $B, C)$. Ectopic breast tissue was present around the tumour (white arrow). The epithelial and stromal growth revealed a leaf-like architecture (haematoxylin and eosin staining .

to the inguinal area. ${ }^{12}$ Axillary EBT is present in $2 \%-6 \%$ of women. ${ }^{2}$ In contrast, phyllodes tumours account for less than $1 \%$ of all breast tumours, ${ }^{3}$ and only a few cases have been reported. ${ }^{124-6}$ To the best of our knowledge, this is the first report of a CT image of a phyllodes tumour arising in the 
axillary EBT. The CT image in this case is notable because it shows that tumours arising in the axillary EBT may present as lesions near the medial upper arm on CT, even if they appear as common axillary masses on US. Axillary lymphadenopathy is usually the primary consideration for a well-circumscribed mass in the axilla on US. However, tumours arising in axillary EBT should be considered as a differential diagnosis, particularly when the mass is present in an atypical axillary region on CT. To evaluate the precise anatomical location of a mass, it is important to make a comprehensive judgement from multiple modalities such as US and CT. A CT image may help to distinguish tumours arising in the axillary EBT from axillary lymphadenopathy.

\section{Learning points}

- Phyllodes tumours arising in the ectopic axillary breast tissue are extremely rare and can mimic lymphadenopathy on imaging.

- A CT image may help to distinguish tumours arising in the ectopic axillary breast tissue from axillary lymphadenopathy as the former can present as lesions near the medial upper arm.

Contributors Conception and design of study: AF and KM. Acquisition of data: AF and TH. Analysis and/or interpretation of data: AF and KM. Drafting the manuscript: AF. Revising the manuscript critically for important intellectual content: KM and TS. Approval of the version of the manuscript to be published: AF, KM, TH and TS.
Funding The authors have not declared a specific grant for this research from any funding agency in the public, commercial or not-for-profit sectors.

Competing interests TS reports personal fees from ASKA Pharmaceutical, Astra Zeneca K.K.,Eisai, Ono Pharmaceutical, Taiho Pharmaceutical,Takeda Pharmaceutical, Chugai Pharmaceutical, Eli Lilly Japan K.K.,Novartis Pharma K.K., Pfizer Inc.,MiRTeL,Meiji Seika Pharma, Nippon Kayaku, grants from Eisai, Kyowa Hakko Kirin,Taiho Pharmaceutical, Chugai Pharmaceutical, Nippon Kayaku, outside the submitted work.

Patient consent for publication Obtained.

Provenance and peer review Not commissioned; externally peer reviewed.

ORCID iD

Akihiro Fujimoto http://orcid.org/0000-0003-4261-7984

\section{REFERENCES}

1 Oshida K, Miyauchi M, Yamamoto N, et al. Phyllodes tumor arising in ectopic breast tissue of the axilla. Breast Cancer 2003;10:82-4.

2 Nigam JS, Garg P, Talukder S. Ectopic breast tissue lesion in axilla: cytology report of two cases. Diagn Cytopathol 2019;47:793-6.

3 Kilitci A, Arıoz 0. Primary benign phyllodes tumor of the vulva: case report and review of literature. Eur J Breast Health 2019;15:196-9.

4 Saleh HA, Klein LH. Cystosarcoma phyllodes arising synchronously in right breast and bilateral axillary ectopic breast tissue. Arch Pathol Lab Med 1990;114:624-6.

5 Petrillo A, Petrillo M, Fulciniti F, et al. Primary phyllodes tumor of the axilla: DCE-MRI findings with 1.5T breast-dedicated system and pathological correlation. Breast J 2011;17:525-7

6 Ruvalcaba-Limón E, Bautista-Piña V, Ramírez-Bollas J, et al. A nonpalpable nodule in ectopic axillary breast tissue: consider phyllodes tumor. Case Rep Pathol 2016;2016:3603262:4

Copyright 2021 BMJ Publishing Group. All rights reserved. For permission to reuse any of this content visit

https://www.bmj.com/company/products-services/rights-and-licensing/permissions/

BMJ Case Report Fellows may re-use this article for personal use and teaching without any further permission.

Become a Fellow of BMJ Case Reports today and you can:

- Submit as many cases as you like

- Enjoy fast sympathetic peer review and rapid publication of accepted articles

- Access all the published articles

Re-use any of the published material for personal use and teaching without further permission

Customer Service

If you have any further queries about your subscription, please contact our customer services team on +44 (0) 2071111105 or via email at support@bmj.com.

Visit casereports.bmj.com for more articles like this and to become a Fellow 